\title{
Inovasi E-Lampid Sebagai Implementasi New Public Service dalam Meningkatkan Kualitas Pelayanan Disdukcapil Kota Surabaya
}

\author{
F. Dinda Aryani ${ }^{1}$; Arum Kusuma Hastuti ${ }^{2}$; Wahyu Rohmawati ${ }^{3}$; Aulia Nur \\ Kasiwi $^{4}$; Atik Septi Winarsih ${ }^{5}$ \\ 1,2,3,4,5 Universitas Muhammadiyah Yogyakarta,wahyurohma@gmail.com
}

\begin{abstract}
Abstrak
New public service merupakan model baru setelah munculnya new public management dan sebagai model pelayanan yang lebih mengutamakan kepentingan masyarakat. Pelaksanaan new public service telah diterapkan pada beberapa instansi pemerintah di Indonesia sebagai wujud meningkatkan kualitas pelayanan yang diberikan oleh pemerintah untuk masyarakat. Salah satu instansi pemerintah yang telah menerapkan model new public service adalah Dinas Kependudukan dan Catatan Sipil Kota Surabaya dengan proses pelayanan menggunakan aplikasi E-Lampid. Aplikasi ini merupakan inovasi yang diciptakan oleh pemerintah Kota Surabaya dan diserahkan kepada Disdukcapil untuk mengatasi banyaknya antrian masyarakat yang membutuhkan layanan administrasi kependudukan. Tujuan dari penelitian ini adalah untuk menjelaskan pelaksanaan aplikasi E-Lampid di Kota Surabaya sebagai bagian dari implementasi new public service. Penelitian ini menggunakan metode kualitatif dengan menggunakan sumber data yang berupa data sekunder dimana data-data yang diperoleh berasal dari studi terdahulu seperti literatur, berita online, jurnal ilmiah, website pemerintah yang relevan dan berkaitan dengan topik pembahasan penelitian. Teknik analisis data dengan menggunakan kajian literature review dalam kurun waktu 2010-2020. Hasil penelitian menunjukkan bahwa pelaksanaan dari aplikasi E-Lampid telah mengatasi permasalahan yang ada dalam penyelengaraan pelayanan publik di Disdukcapil kota Surabaya. Aplikasi ini dapat diakses oleh masyarakat Surabaya secara online sehingga memudahkan masyarakat dalam melakukan pembaharuan informasi data diri.
\end{abstract}

Kata kunci : E-Lampid, Implementasi, New Public Service, Pelayanan Publik.

\begin{abstract}
New public service is a new model after new public management and as a service model that prioritizes the interests of the society. The implementation of the new public service has been implemented in several government agencies in Indonesia as a form of improving the quality of services provided by the government to the society. One of government agency that has implemented the new public service model is the Surabaya City Population and Civil Registry Service with the service process using the E-Lampid application. This application is an innovation created by the Surabaya City government and submitted to Disdukcapil to overcome the many queues of people who need population administration services. This study aims to explain the implementation of E-Lampid application in the city of Surabaya as part of the implementation of the new public service. This study uses a qualitative method by using data sources in the form of secondary data where the data obtained comes from previous studies such as literature, online news, scientific journals, government websites that are relevant and related to the topic of research discussion. The data analysis technique used a literature review study in the period 2010-2020. The results showed that the implementation of the E-Lampid application has overcome the problems that exist in the provision of public services in the Disdukcapil city of Surabaya. This application can be accessed by the people with online step, making it easier for the public to update their personal data information.
\end{abstract}

Keywords : E-Lampid, Implementation, New Public Service, Public Service. 


\section{Pendahuluan}

Pada dasarnya pelayanan publik melibatkan berbagai aspek dari kehidupan masyarakat yang begitu luas. Pemerintah sebagai penyelenggara pelayanan publik mempunyai fungsi untuk memberikan pelayanan yang optimal kepada masyarakat sesuai dengan aturan yang berlaku dalam memenuhi kebutuhan tiap masyarakatnya. Dalam hal ini sebagai pihak yang bertanggung jawab untuk dapat memberikan pelayanan publik, pemerintah harus memiliki upaya dan bekerja keras memberikan sebuah pelayanan yang maksimal guna meningkatkan kualitas pelayanan. Sebab pemerintah mempunyai kewajiban dalam memberikan pelayanan publik yang harus dilaksanakan dan berjalan dengan semestinya agar tidak terciptanya kemandekan (Abdussamad, 2019). Instansi pemerintahan yang berfokus di bidang pelayanan publik, salah satunya Dinas Kependudukan dan Pencatatan Sipil yang bertugas untuk menyediakan pelayanan kepada masyarakat berkaitan dengan akta kelahiran, akta kematian, Kartu Tanda Penduduk, dan lainnya yang berhubungan dengan kependudukan dimana setiap tahunnya kebutuhan tersebut semakin meningkat.

Kependudukan merupakan fokus dan inti utama dari berbagai permasalahan pembangunan. Hampir seluruh kegiatan dalam pembangunan berkenaan dengan penduduk, oleh sebab itu penduduk harus menjadi tokoh utama sekaligus berperan menjadi objek dalam pembangunan. Kepmenpan Nomor 63 Tahun 2003 mendeskripsikan jika "ukuran keberhasilan penyelenggaraan pelayanan ditentukan oleh tingkat kepuasan penerima pelayanan". Maka adanya kepuasan dari masyarakat menunjukkan keberhasilan pelaksanaan pelayanan publik yang dilakukan oleh pemerintah (Damayanti, Suwena, \& Haris, 2019). Dengan demikian, pelayanan kependudukan menjadi salah satu pilar untuk menjamin adanya pengakuan, perlindungan, dan kevalidan data penduduk (Tryanti \& Frinaldi, 2019).

Masyarakat setiap saat jika membutuhkan pelayanan publik selalu menuntut pelayanan prima dari pemerintah, walaupun tuntutan tersebut seringkali tidak sesuai dengan yang diharapkan. Sebab kenyataannya pelayanan publik yang telah terjadi sejauh ini masih terkesan berbelit-belit, tidak tepat waktu, lambat, dan bahkan terkadang mendahulukan kerabat (Nugroho \& Murtiningsih, 2016). 
Seharusnya setiap masyarakat mempunyai hak untuk menikmati pelayanan yang diberikan oleh pemerintah karena pada dasarnya masyarakatlah yang menjadi seseorang yang dapat mengukur baik ataupun buruknya kualitas pelayanan publik. Dalam hal ini, pemerintah sebagai "public service" perlu menciptakan pelayanan yang bisa memberikan jaminan kepuasan untuk masyarakatnya dengan menyeluruh (Partiwi, 2020).

Dinas Kependudukan dan Pencatatan Sipil menyediakan layanan dalam hal administrasi kependudukan dengan terdapatnya kegiatan dalam rangka penataan maupun penertiban publikasi dokumen serta data-data penting terkait kependudukan melalui pendaftaran dan pencatatan penduduk, informasi mengenai administrasi kependudukan, serta mengimplementasikan hasilnya dalam pelayanan publik. Dimana dokumen yang berkaitan dengan kependudukan sangat dibutuhkan oleh masyarakat di dalam kehidupan setiap harinya (Purwanto \& Santoso, 2018). Adapun pelayanan yang diselenggarakan oleh pemerintah untuk memenuhi kebutuhan masyarakat khususnya dalam bidang pelayanan pencatatan sipil adalah mencatat peristiwa penting yang dialami oleh masyarakat, seperti adanya peristiwa kelahiran ataupun kematian. Hal tersebut merupakan sebagai tanggung jawab pemerintah di Dinas Kependudukan dan Pencatatan Sipil.

Salah satu kewajiban dari Dinas Kependudukan dan Pencatatan Sipil yaitu melakukan pencatatan sipil untuk setiap masyarakatnya. Pencatatan sipil merupakan pencatatan yang dilakukan oleh instansi pemerintah yang bersifat permanen serta berkelanjutan, dengan bersifat wajib dan menyeluruh atas adanya kejadian penting yang telah dialami oleh masyarakat sesuai dengan kebijakan yang berlaku di suatu negara. Pencatatan sipil merupakan pengakuan negara atas status pribadi dan status hukum masyarakat yang berkenaan dengan status pribadi seseorang. Apabila ingin melakukan pencatatan dan atau perubahan status pribadi seseorang maka wajib baginya untuk mengurus kebutuhan tersebut ke instansi terkait yaitu bidang pelayanan pencatatan sipil untuk segera diperbaharui.

Seperti yang telah dilakukan di beberapa daerah lainnya, misalnya inovasi Pelangi (Pelayanan Langsung Jadi) yang dilakukan oleh Disdukcapil Kota Banda Aceh bertujuan untuk memberikan kemudahan kepada masyarakat untuk 
memperoleh berkas akta kelahiran dengan tidak dipungut biaya apapun serta masyarakat tidak perlu mengantri lagi seperti pada umumnya (Zamharira \& Cahyani, 2019). Bukti keberhasilan dari adanya inovasi ini yaitu setelah diluncurkannya inovasi Pelangi pada tahun 2015 telah meningkatkan jumlah masyarakat yang memiliki akta kelahiran di Kota Banda Aceh. Penerapan inovasi Digi Mobile dalam meningkatkan pelayanan publik Dispenduk Kota Pariaman dapat dikatakan memenuhi kriteria berhasil serta efektif dan efisien. Adapun faktor pendukung yang mempengaruhi keberhasilan inovasi Digi Mobile yaitu mudahnya bagi masyarakat dalam mengunduh aplikasi serta memudahkan dalam mendapatkan akses. Sehingga memberikan kemudahan kepada setiap masyarakat dalam pengurusan dokumen kependudukan baik yang berada di domisili yang sama ataupun yang berada di luar domisili (Dahlila \& Frinaldi, 2020).

Keberhasilan lainnya yaitu Dinas Kependudukan dan Pencatatan Sipil Kota Malang memberikan suatu inovasi pelayanan publik yang berbasis IT (online) mengenai administrasi kependudukan yaitu bernama GAMPIL (Gesit, Aktif, dan Merakyatnya Dispendukcapil Kota Malang). Tujuan dari aplikasi tersebut adalah untuk memudahkan dan mempercepat proses pengurusan akta kelahiran, kartu keluarga, KTP dan akta kematian. Pelaksanaan dari aplikasi GAMPIL telah melakukan penyederhanaan terhadap mekanisme pelayanan sesuai dengan standar pelayanan yaitu, Paket Hemat $(\mathrm{PaHe})$ ialah data kependudukan dengan masyarakat memberikan lampiran berupa persyaratan satu jenis data tetapi mendapatkan data kependudukan lainnya sehingga tidak perlu mengurusnya dari awal, Metode Jemput dan Antar Bola ialah pelayanan yang dilakukan oleh penyelenggara layanan dengan datang langsung kerumah untuk mengambil persyaratan dan penyerahan data kependudukan yang diprioritaskan bagi masyarakat yang mengalami keterbatasan, serta perekaman e-KTP masyarakat oleh petugas penyelenggara di lokasi tempat-tempat umum (Pebriani \& Rohman, 2019).

Pengertian pelayanan publik ialah pelayanan yang nantinya diberikan kepada masyarakat secara umum sebagai warga negara yang sah (Saefullah, 2008). Pelayanan publik dapat dimaknai pula sebagai penyedia layanan untuk memenuhi keperluan masyarakat yang berkepentingan dengan organisasi sesuai pada aturan 
maupun prosedur yang sudah ditetapkan (Robi'ah, 2016). Tujuan dari adanya pelayanan publik pada dasarnya ialah untuk dapat memuaskan setiap masyarakatnya, terlebih dalam rangka menciptakan kepuasan bagi masyarakat terutama untuk mencapai kualitas pelayanan yang maksimal. Untuk dapat meningkatkan pelayanan publik khususnya pada pelayanan administrasi kependudukan, maka dibutuhkan suatu inovasi yang lebih maju dalam pengimplementasiannya. Penyedia pelayanan publik tersebut pun dituntut untuk dapat memberikan pelayanan yang berbasis tekologi dan cenderung lebih cepat, mudah, efektif, dan efisien. Di jaman sekarang inovasi pelayanan tersebut sangat dibutuhkan, terlebih dalam hal pelayanan administrasi kependudukan sebagai upaya untuk meningkatkan mutu pelayanan masyarakat. Inovasi pelayanan publik merupakan jenis pelayanan publik yang berisi gagasan atau ide baru yang dapat memberikan manfaat besar untuk masyarakat.

Terdapatnya data dari Badan Pusat Statistik Kota Surabaya jika jumlah penduduk yang terdapat di Kota Surabaya pada tahun 2010 hingga 2020 terdapat peningkatan jumlah penduduk yaitu sebanyak 108,8 ribu orang atau naik 3,94\%. Dengan demikian, pertumbuhan jumlah penduduk yang ada di Kota Surabaya setiap tahunnya mengalami peningkatan yang cukup signifikan. Pencatatan data kependudukan pun harus dilakukan agar data valid sesuai dengan keadaan yang ada. Maka kemudian sebuah inovasi harus dilakukan agar pencatatan dapat berjalan lancar secara terus menerus mengikuti pertumbuhan penduduk. Dengan latar belakang tersebut, pemerintah Kota Surabaya melalui Dinas Komunikasi dan Informatika meluncurkan sebuah inovasi dengan adanya sistem aplikasi yang bernama "E-Lampid" yang merupakan kepanjangan dari "Elektronik Lahir, Mati, Pindah, Datang”. Aplikasi tersebut kemudian diserahkan kepada Disdukcapil Kota Surabaya selaku pelaksana (Dewi, 2016). E-Lampid tersebut bertujuan untuk lebih bisa menertibkan setiap masyarakat yang ada di Kota Surabaya untuk tertib dalam beradministrasi kependudukan. Maka dari itu, penelitian yang kami lakukan ini memiliki tujuan untuk mengetahui gambaran secara lebih menyeluruh yang berkaitan dengan inovasi pelayanan publik melalui sistem aplikasi E-Lampid di Kota Surabaya. 


\section{Metode}

Fokus penelitian ini berkaitan dengan sistem aplikasi E-Lampid di Dinas Kependudukan dan Pencatatan Sipil Kota Surabaya sebagai upaya peningkatan kualitas pelayanan. Penelitian ini dilakukan dengan menggunakan metode penelitian kualitatif. Penelitian kualitatif yaitu suatu metode dalam rangka memahami dan mempelajari makna yang terdapat pada setiap individu ataupun kelompok dengan beranggapan jika munculnya suatu fenomena berasal dari adanya permasalahan sosial (Creswell, 2009). Penelitian ini pun dilakukan dengan menggunakan sumber data yang berupa data sekunder dimana data-data yang kami peroleh untuk mendapatkan hasil penelitian yaitu berasal dari studi terdahulu seperti misalnya literatur, berita online, jurnal ilmiah, website pemerintah yang relevan dan berkaitan dengan topik pembahasan penelitian ini. Dalam hal ini, data sekunder ialah data yang diperoleh secara tidak langsung yaitu melalui media perantara untuk memahami sekaligus mempelajari data yang didapatkan sebagau sebuah informasi (Sugiyono, 2012). Teknik analisis data dengan menggunakan kajian literature review dengan menggunakan kata kunci E-Lampid; Disdukcapil; Kota Surabaya dalam kurun waktu 2010-2020.

\section{Hasil dan Pembahasan}

\section{Inovasi E-Lampid Sebagai Implementasi New Public Service dalam Meningkatkan Kualitas Pelayanan Disdukcapil Kota Surabaya}

New public service menjadi model baru setelah munculnya new public management. Dalam memberikan pelayanan, new public service lebih mengutamakan masyarakat sebagai pelanggan yang dilayani dengan maksimal (Yusfadhiyah, 2018). Adapun pelaksanaan serta pengaplikasian dari new public service sendiri telah banyak dilakukan oleh berbagai instansi pemerintah sebagai penyelenggara pelayanan publik di Indonesia. Model pelayanan new public service bertopang pada teori demokrasi yang mana menjunjung tinggi adanya persamaan hak warga negara. Penyelenggara pelayanan publik memiliki tanggung jawab penuh kepada masyarakat dengan mengutamakan pada kepentingan masyarakat 
(Denhardt \& Denhardt, 2007). Menurut Denhardt terdapat prinsip tentang new public service, diantaranya "service citizens not customer, seek the public interest, value citizenship over entrepreneurship, strategically act democratically recognize that accountability is not simple, serve rather than steer, value people not just productivity" (Syahruddin, Insi, \& Prasetyo, 2020).

Contoh pelaksanaan new public service di Indonesia di antaranya pertama, pelaksanaan smart city di Kota Bandung dalam rangka mengaplikasikan new publice service. Adapun pengaplikasiannya yaitu dengan cara memberikan pelayanan yang maksimal kepada masyarakat agar lebih mudah mengakses melalui taman Wi-Fi, E-Budgeting, aplikasi, website resmi, layanan pengaduan online, dan lain sebagainya (Alim, Kumala, \& Hair, 2019). Kedua, implementasi new public service dalam pelayanan kesehatan. Hal tersebut dilakukan dalam rangka mengoptimalkan pelayanan kesehatan melalui BPJS kesehatan dengan cara menyederhanakan prosedur serta memberikan ruang penilaian dari masyarakat untuk mengetahui seberapa tinggi indeks kepuasan masyarakat setelah menggunakan pelayanan BPJS kesehatan (Sumarto, 2018). Ketiga, pelayanan perizinan di Kabupaten Malang dengan berbasiskan pada new public service yang mengutamakan citizen centric. Adapun pelaksanaannya yaitu dengan memanfaatkan adanya teknologi informasi dan komunikasi sebagai upaya guna lebih mendekatkan masyarakat sebagai pengguna kepada pemerintah sebagai penyelenggara, sehingga terwujudnya interaksi yang positif serta saling menguntungkan diantara keduanya (Suharnoko, Chayatin, \& Dinata, 2018).

Dinas Kependudukan dan Pencatatan Sipil merupakan salah satu instansi pemerintah yang turut mengaplikasikan new public service dengan tujuan untuk meningkatkan kualitas pelayanan publik yang lebih optimal. Dinas Kependudukan dan Pencatatan Sipil Kota Surabaya adalah salah satu intansi yang berada di bawah pemerintah Kota Surabaya. Dinas Kependudukan dan Pencatatan Sipil Kota Surabaya mempunyai wewenang untuk melaksanakan regulasi administrasi kependudukan, yang mana administrasi kependudukan yaitu salah satu wujud penertiban kependudukan. Adapun visi dari Dinas kependudukan dan Pencatatan Sipil Kota Surabaya ialah "Pelayanan Prima Tertib Administrasi Kependudukan" 
(Rahmawati, 2015). Dengan adanya pelayanan yang prima dari Disdukcapil sendiri tentunya akan menciptakan masyarakat yang lebih tertib terhadap administrasi kependudukan. Selain itu, identitas kependudukan tiap masyarakat selalu update yang terbaru dan pastinya lebih lengkap. Sejalan dengan visinya, terdapat pula moto dari Dinas Kependudukan dan Pencatatan Sipil Kota Surabaya yaitu, "Dinas Kependudukan dan Pencatatan Sipil Makin Mudah dan Dekat dengan Masyarakat” (Rahmawati, 2015).

Kota Surabaya merupakan salah satu kota terbesar yang ada di Indonesia. Adanya hal tersebut membuat Kota Surabaya memiliki kepadatan jumlah penduduk yang tinggi dan menjadikan Kota Surabaya sebagai kota dengan kepadatan penduduk paling tinggi di Provinsi Jawa Timur hingga saat ini. Khususnya pada tahun 2014 menurut data BPS Jawa Timur, Kota Surabaya memiliki jumlah penduduk sebanyak 2.833.924 jiwa. Di tahun tersebut pemerintah Kota Surabaya melalui Diskominfo menciptakan sebuah inovasi baru yang mana memiliki tujuan dalam rangka mempermudah dan mempersingkat pelayanan serta meminimalisir terjadinya kesalahan dalam proses pelayanan khususnya pelayanan pencatatan sipil. Selain itu, inovasi tersebut pun berguna untuk mempermudah pemerintah Kota Surabaya dalam melakukan pembaharuan data kependudukan (Rozani, Mutiasari H, \& Rachmania A, 2019).

Aplikasi E-Lampid merupakan inovasi yang diciptakan oleh pemerintah Kota Surabaya yang diserahkan kepada Disdukcapil sebagai implementasi new public service. Latar belakang hadirnya aplikasi E-Lampid adalah karena berawal dari banyaknya penduduk di Kota Surabaya yang membutuhkan layanan administrasi, sehingga menyebabkan antrian yang panjang di Disdukcapil. Untuk mengatasi antrian yang panjang maka pemerintah Kota Surabaya membuat salah satu inovasi baru yang berbasiskan pada online dan masyarakat bisa dengan mudah mengaksesnya setiap saat yang kemudian diserahkan kepada Disdukcapil. Hal tersebut pun sebagai upaya dalam memaksimalkan penggunaan teknolgi dengan maksimal di lingkungan pemerintah. Apabila E-Lampid dapat diterapkan dengan baik dan sesuai dengan prosedur yang telah ditetapkan maka kualitas penyelenggaraan pelayanan di Disdukcapil dapat meningkat sesuai dengan 
keinginan masyarakat. Aplikasi E-Lampid telah mencapai model Government to Citizen dengan dapat dimaknai dengan adanya hubungan diantara pemberian layanan yang dilakukan oleh pemerintah untuk memenuhi kebutuhan warga negaranya (Fang, 2002). Hubungan ini merupakan tujuan utama dari e-government dimana memudahkan warga negara memperoleh pelayanan dari pemerintah sebegai penyelenggara pelayanan dengan nyaman, cepat, serta efektif dan efisien.

Selain mencapai model Government to Citizen, aplikasi E-Lampid juga telah mencapai model Government to Government. Model G2G merupakan sebuah interaksi antara pemerintah daerah (Disdukcapil) dan pemerintah pusat (Kementerian Dalam Negeri) (Noviyanti \& Gamaputra, 2020). Dengan model ini memungkinkan komunikasi antar pemerintah/instansi dapat terlaksana dengan menggunakan sistem online sehingga data dapat tersampaikan secara efektif dan efisien. Selain itu, model G2G juga merupakan interaksi antar pemerintah dalam wilayah tersebut yaitu antara Disdukcapil dengan instansi lainnya. Disdukcapil Kota Surabaya dengan Dinas Komunikasi dan Informatika melakukan koordinasi dalam hal teknis penyelenggaraan E-Lampid, seperti apabila terjadi kendala teknis dalam pengaksesan oleh masyarakat maka Diskominfo dapat membantu menanganinya. Kemudian, Disdukcapil Kota Surabaya dan Biro Perencanaan Pembangunan melakukan interaksi dalam hal pengembangan kota pintar di Kota Surabaya. Selain itu, interaksi G2G terdapat pada Dinas Kesehatan yang bekerjasama dengan beberapa puskesmas dan rumah sakit di Surabaya. Puskesmas dan rumah sakit tersebut melayani pengurusan pencatatan kependudukan secara online seperti akta kelahiran dan KK sehingga masyarakat tidak perlu datang ke kantor untuk mengurus administrasi kependudukan.

E-Lampid sendiri memiliki kepanjangan dari "Lahir, Mati, Pindah, dan Datang”. Dalam aplikasi E-Lampid terdapat 16 pelayanan dengan 6 layanan yang utama seperti akta kelahiran, surat permohonan kawin, surat keterangan pindah, surat keterangan datang, surat permohonan cerai dan akta kematian. Inovasi pelayanan E-Lampid bukan hanya dapat memberikan sebuah untungan secara ekonomi bagi Disdukcapil itu sendiri, tetapi juga membrikan sebuah keuntungan secara ekonomi untuk masyarakatnya. Adapun keuntungan lain dari segi ekonomi 
ialah dapat menghindari para calo untuk memungut biaya yang besar dari masyarakat dalam hal mengurus proses administrasi kependudukan yang masyarakat butuhkan (Fadilah \& Maesaroh, 2020). Dengan adanya hal tersebut, Disdukcapil Kota Surabaya memberikan sebuah inovasi pelayanan yang prima dengan pelaksanaan aplikasi E-Lampid yang tidak memungut biaya sedikit pun.

Adapun langkah-langkah dalam menggunakan aplikasi E-Lampid agar masyarakat dapat menggunakannya dengan baik dan benar yaitu dengan cara masyarakat Kota Surabaya mengunjungi laman aplikasi tersebut (https://klampiddispendukcapil.surabaya.go.id/) kemudian melakukan pendaftaran data diri dan melakukan serta mengajukan verifikasi dengan cara mengunggah foto KTP dan melakukan foto diri dengan membawa KTP. Setelah proses tersebut dilakukan maka masyarakat menunggu diverifikasi akunnya selama 1 x 24 jam. Kemudian masyarakat membaca dan menyetujui syarat serta ketentuan yang tercantum pada aplikasi tersebut. Tahapan selanjutnya, masyarakat mengklik tombol "Ya, saya setuju". Jika akun sudah terdaftar, masyarakat sebagai pemohon sudah dapat mengajukan permohonan melalui aplikasi tersebut. Sedangkan, masyarakat yang telah membuat akun E-Lampid dan mengajukan permohonan pelayanan yang ada di aplikasi tersebut tetap harus melakukan verifikasi secara offline dengan mendatangi kantor Disdukcapil dan membawa berkas-berkas penting yang berhubungan dengan proses pelayanan yang dibutuhkan oleh masyarakat (Duhita, 2018).

Walaupun sudah terdapat layanan secara daring yang sudah disediakan oleh pemerintah di Disdukcapil agar memudahkan layanan yang cepat, namun pemerintah Disdukcapil Kota Surabaya pun masih menyediakan pelayanan secara offline. Hal ini dilakukan karena masih banyak masyarakat yang belum paham dan mengalami kesulitan dalam penggunaan aplikasi E-Lampid. Disdukcapil Kota Surabaya tetap menggunakan cara lama yaitu secara konvensional (offline) dengan masyarakat yang membutuhkan pelayanan dapat mendatangi kantor secara langsung dan mengisi formulir data diri secara manual sesuai dengan tujuan dan kepentingannya (Duhita, 2018). Hal tersebut menunjukkan bahwa pemerintah Disdukcapil Kota Surabaya masih memikirkan masyarakat yang belum paham 
terhadap teknologi yang berkembang saat ini. Sebab walaupun sudah ada pelayanan yang lebih mudah secara online, akan tetapi pemerintah masih berusaha tidak meninggalkan cara konvensional.

Aplikasi E-Lampid yang diterapkan di Disdukcapil Kota Surabaya saat ini telah menjadi suatu contoh yang baik dalam bidang pelayanan publik untuk 40 kepala daerah lainnya yang ada di Indonesia. Adapun contoh daerah yang ingin menerapkan adanya aplikasi E-Lampid misalnya saja seperti pemerintah Provinsi Riau, Sumatera Utara, Kota Medan, dan lain sebagainya (Rozani et al., 2019). Apabila pemerintah daerah lainnya ingin menerapkan aplikasi tersebut, maka diharapkan harus tetap konsisten dalam mengambil keputusan dan menetapkan kebijakan untuk dapat mencapai target yang diinginkan. Selain itu, diperlukan pengawasan dalam setiap pembuatan kebijakan agar lebih meningkatkan kualitas pelayanan.

Dalam pelaksanaan aplikasinya terdapat faktor pendukung seperti : sumber daya manusia yang mana sebagai pelaksana inovasi tersebut yaitu pemerintah Kota Surabaya, Disdukcapil, Diskominfo, Administrasi perlengkapan, pihak kelurahan, rumah sakit, puskesmas (Fadilah \& Maesaroh, 2020). Selain itu, dari segi perlengkapan didukung dengan adanya Broadband Learning Center (BLC) yang berada hampir di seluruh kelurahan dan kecamatan Kota Surabaya (Yuniar, Setiawan, \& Ulfah, 2019). Disamping terdapat faktor pendukung, namun terdapat pula faktor penghambat dalam pelaksanaannya sehingga menghambat kualitas dari inovasi pelayanan publik itu sendri. Faktor penghambatnya seperti pandangan masyarakat yang hingga saat ini masih terbiasa dengan proses pelayanan publik yang secara offline, ketidakefektifan dalam pengiriman dokumen kepada masyarakat (masih sering terjadinya kesalahan dalam alamat pengiriman).

\section{Kesimpulan}

Berdasarkan penjelasan yang telah dipaparkan di atas, maka dapat disimpulkan bahwa Dinas Kependudukan dan Pencatatan Sipil Kota Surabaya telah menerapkan New Public Service. Terbukti dengan adanya inovasi E-Lampid yang bertujuan untuk meningkatkan kualitas pelayanan kepada masyarakat. Aplikasi E- 
Lampid hadir sebagai suatu inovasi pelayanan secara online untuk mengatasi antrian yang panjang di Disdukcapil. Hal tersebut juga sebagai upaya dalam memaksimalkan penggunaan teknolgi dengan maksimal di lingkungan pemerintah. Aplikasi ini telah bekerjasama dengan instansi pemerintah lainnya yang ada di wilayah tersebut seperti Dinas Komunikasi dan Informatika, Dinas Kesehatan dan Biro Perencanaan Pembangunan.

Aplikasi E-Lampid dapat diakses oleh masyarakat Surabaya secara online sehingga memudahkan masyarakat dalam melakukan pembaharuan informasi data diri. Di dalam pelaksanaannya walaupun terdapat berbagai pendukung yang ada namun masih terdapat hambatan bagi masyarakat yang mana masih ada masyarakat yang belum terbiasa dengan sistem online dan cenderung lebih nyaman dengan sistem pelayanan offline. Tetapi dalam pelaksanaannya, pemerintah Disdukcapil Kota Surabaya juga masih menyediakan pelayanan secara offline dengan datang langsung ke kantor Disdukcapil. Hal tersebut dilakukan karena masih banyak masyarakat yang belum paham dan mengalami kesulitan dalam penggunaan aplikasi E-Lampid. Aplikasi ini telah menjadi contoh bagi kota lainnya di Indonesia sehingga membuktikan bahwa penggunaan dan pemanfaatan teknologi dalam proses pelayanan publik akan memudahkan serta membantu masyarakat dan pemerintah.

Penelitian ini juga memberikan rekomendasi kebijakan pada penggunaan ICT (Information Communication and Technology) di tingkat kabupaten untuk dapat melaksanakan one single window dalam proses pembuatan legalitas Lahir, Mati, Pindah, Datang untuk bisa diterapkan pada setiap tingkat pelayanan daerah. Saran untuk Disdukcapil Kota Surabaya ialah selalu menjaga koordinasi yang baik antar instansi pemerintahan dalam pelaksanaan aplikasi E-Lampid serta melakukan sosialisasi secara rutin kepada masyarakat untuk dapat mendekatkan dan mendorong penggunaan aplikasi ini, sehingga terdapat peningkatan penggunaan aplikasi E-Lampid. Kegiatan tersebut dapat berdampak positif bagi Disdukcapil Kota Surabaya karena menunjukkan keberhasilan dalam mengelola keefektivan pengurusan administrasi kependudukan dan juga sebagai contoh untuk kota lainnya agar lebih dapat tertarik lagi untuk mengadopsi aplikasi tersebut. 


\section{Referensi}

Abdussamad, J. (2019). Kualitas Pelayanan Publik Di Kantor Dinas Kependudukan

Dan Catatan Sipil Kabupaten Gorontalo. Publik: Jurnal Manajemen

Sumber Daya Manusia, Administrasi Dan Pelayanan Publik, 6(2), 73-

82. https://doi.org/10.37606/publik.v6i2.6

Alim, S., Kumala, A., \& Hair, A. (2019). New Public Service In Bandung Through

The Concept Of Smart City New Public Service Kota Bandung Melalui

Konsep Smart City. Journal of Politic and Policy, 2(1), 95-108.

Retrieved from https://jppol.ub.ac.id/index.php/jppol/article/view/20

Creswell, J. W. (2009). Qualitative Inquiry and Research Design: Choosing Among Five Approaches. Thousand Oaks: Sage.

Dahlila, D., \& Frinaldi, A. (2020). Inovasi Dukcapil Digi Mobil Dalam

Meningkatkan Pelayanan Publik Pada Dinas Kependudukan Dan

Pencatatan Sipil Kota Pariaman. JESS (Journal of Education on Social

Science), 4(2), 241. https://doi.org/10.24036/jess.v4i2.285

Damayanti, L. D., Suwena, K. R., \& Haris, I. A. (2019). Analisis Kepuasan Masyarakat Terhadap Pelayanan Publik Berdasarkan Indeks Kepuasan Masyarakat (Ikm) Kantor Kecamatan Sawan Kabupaten Buleleng. Jurnal Pendidikan Ekonomi Undiksha, 11(1), 21. https://doi.org/10.23887/jjpe.v11i1.20048

Denhardt, J. V., \& Denhardt, R. B. (2007). No TThe New Public Service : Serving not Steering (Expanded E). New York: M.E.Sharpe.

Dewi, P. R. (2016). Implementasi E-Lampid di Kantor Kelurahan Kebonsari Kecamatan Jambangan Kota Surabaya. Kajian Kebijakan Publik, 1(1), $1-10$.

Duhita, A. S. (2018). Inovasi Produk E-Lampid dalam Meningkatkan Kualitas Pelayanan Administrasi Kependudukan di Kota Surabaya. Kebijakan Dan Manajemen Publik, 6(2), 1-11. Retrieved from http://journal.unair.ac.id/download-fullpapers-kmp1430c8e0b0full.pdf Fadilah, G. N., \& Maesaroh. (2020). Analisis Inovasi Pelayanan 6 In 1 (Elektronik Lahir Mati Pindah Datang) Di Dispenduk Kota Surabaya (Studi Kasus 
pada Pelayanan Akta Kelahiran dan Akta Kematian). Journal of Public Policy and Management Review, 9(2), 71-87.

Fang, Z. (2002). E-Government in Digital Era: Concept, Practice, and Development. International Journal of The Computer, the Internet and Management, 10(2), 1-22.

Noviyanti, M., \& Gamaputra, G. (2020). The Role of Government in Population and Civil Registration Service Online (E-lampid). 226(Icss), 364-368. https://doi.org/10.2991/icss-18.2018.75

Nugroho, H. W., \& Murtiningsih, S. (2016). Paradoks Gender (Kajian Feminisme Etis terhadap Kemunculan Inong Balee dalam Kekerasan Politik di Aceh). Jurnal Filsafat, 18(3), 295-314. https://doi.org/10.22146/jf.3529

Partiwi, S. (2020). Kualitas Pelayanan Perizinan Satu Pintu di Kabupaten Kebumen. Jurnal E-Bis (Ekonomi-Bisnis), 4(1), 12-24. https://doi.org/10.37339/e-bis.v4i1.249

Pebriani, V., \& Rohman, A. (2019). Analisis Inovasi Pelayanan Publik Gesit Aktif Merakyatnya Dinas Kependudukan Dan Pencatatan Sipil (Gampil) Kota Malang. JISIP: Jurnal Ilmu Sosial Dan Ilmu Politik, 8(1), 122.

Purwanto, S. D., \& Santoso, R. S. (2018). Evaluasi Program Pencatatan Akta Kematian Di Dinas Kependudukan Dan Pencatatan Sipil Kota Semarang. Journal of Public Policy and Management Review, 7(4), 285-298.

Rahmawati, O. D. (2015). Kependudukan dan Catatan Sipil Kota Surabaya ( Studi Pada Pelayanan Pengurusan Akta Kelahiran ). Publika, 3(6), 1-12.

Robi'ah, S. (2016). Pengaruh Kepuasan Kerja Pegawai Terhadap Pelayanan Publik Pada Kantor Kecamatan Sangatta Utara Kabupaten Kutai Utara. Prediksi, 3(3), 66-70.

Rozani, U. R., Mutiasari H, A., \& Rachmania A, N. R. A. (2019). Pelayanan Adsministrasi Kependudukan Kota Surabaya Melalui Program ELAMPID Ditinjau Dari Perspektif Electrnic Government. Jurnal 
Administrasi Dan Kebijakan Publik, 2(3), 255-263. https://doi.org/10.25077/jakp.2.3.255-263.2017

Saefullah, A. D. (2008). Pemikiran Kontemporer Administrasi Publik Perspektif Manajemen Sumber Daya Manusia Dalam Era Desentralisasi. Bandung: LP3AN FISIP UNPAD.

Sugiyono. (2012). Memahami Penelitian Kuantitatif, Kualitatif, dan $R \& D$. Bandung: ALFABETA.

Suharnoko, D., Chayatin, U., \& Dinata, C. (2018). Adaptasi layanan perijinan berbasis teknologi berparadigma new public service dalam meningkatkan kualitas layanan dengan citizen centric. Seminar Nasional Sistem Informasi, 1120-1130.

Sumarto, R. H. (2018). New Public Service Pada Pelayanan Kesehatan (Kajian Pelayanan Kesehatan melalui BPJS Kesehatan). Public Corner, 13(2), 1-12. https://doi.org/10.24929/fisip.v13i2.656

Syahruddin, Insi, N. A., \& Prasetyo, A. J. (2020). Penerapan Kypso Dalam Pelayanan Publik Sebagai Perwujudan New Public Service Paradigm. Jurnal Legislatif, 3(2), 322-346.

Tryanti, W., \& Frinaldi, A. (2019). Efektivitas Implementasi E-Government Dalam Pelayanan Kependudukan Di Dinas Kependudukan Dan Pencatatan Sipil Kota Padang. Journal of Multidicsiplinary Research and Development, 1(3), 424-435.

Yuniar, C., Setiawan, A., \& Ulfah, I. F. (2019). Inovasi Sistem Administrasi Kependudukan Elektronik Lahir Dan Mati Pada Aplikasi E-Lampid. Journal of Chemical Information and Modeling, 53(9), 1689-1699.

Yusfadhiyah, N. S. (2018). Pelaksanaan E-Health pada Puskesmas di Kota Surabaya dilihat dari Perspektif New Public Service. Doctoral Dissertation, Universitas Airlangga, 1-9.

Zamharira, C., \& Cahyani, I. R. (2019). Pelangi: Inovasi Pelayanan Akta Kelahiran Di Kota Banda Aceh. Al-Ijtima `i: International Journal of Government and Social Science, 5(1), 11-20. https://doi.org/10.22373/jai.v5i1.462 